\title{
Fast eiendom - tilbakeføring når en ervervsforutsetning faller bort
}

Av Thor Falkanger, professor emeritus. Nordisk Institutt for Sjørett

Fast eiendom er ikke så sjelden overført-mot eller uten vederlag - for et bestemt formål. Hva skjer med eiendommen når formålet faller bort? Noen eksempler: Veigrunn, tomt til skole, foreningshytte eller grendehus.

\section{INNHOLD}

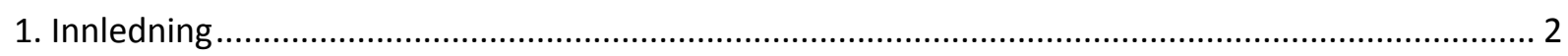

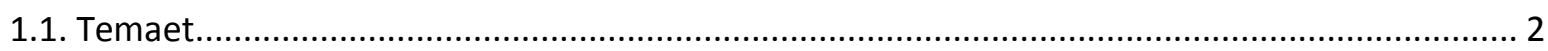

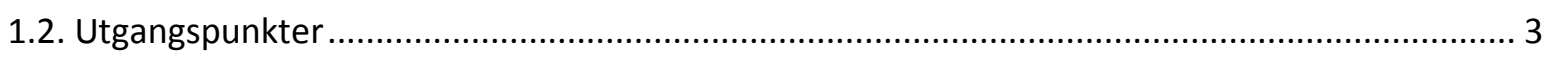

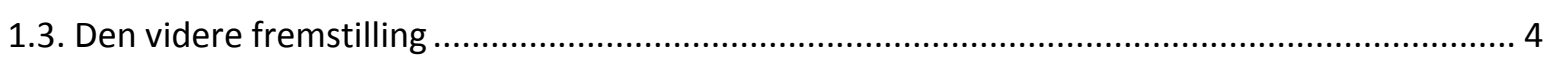

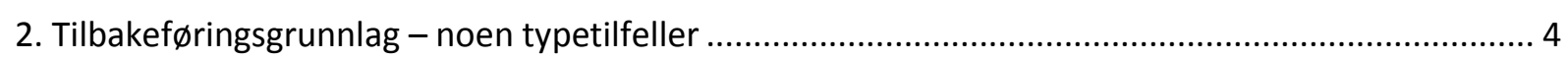

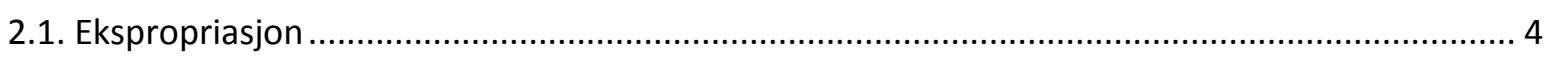

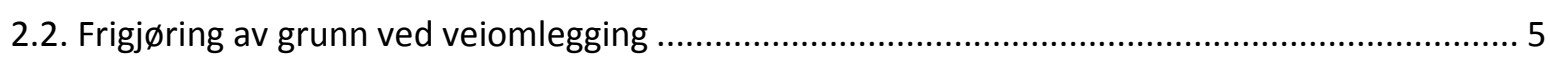

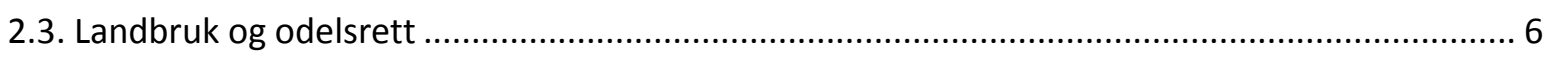

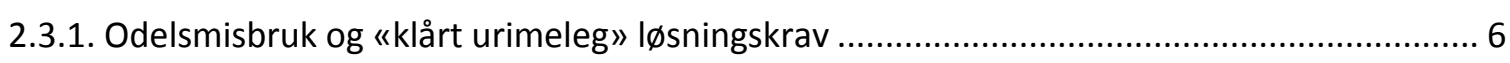

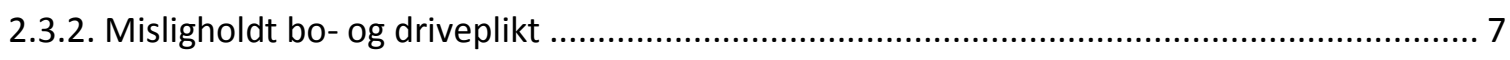

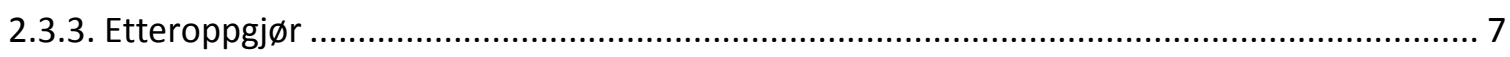

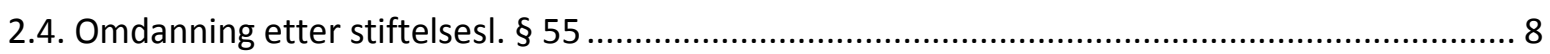

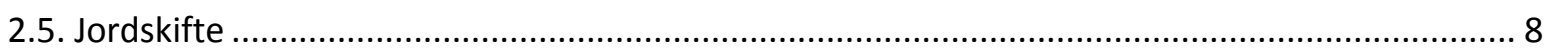

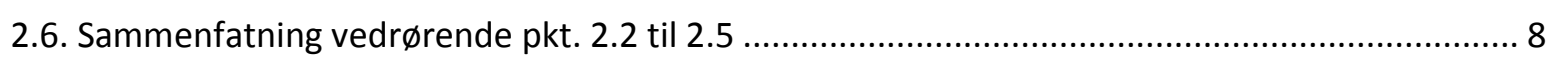

3. De frivillige overføringer - ugyldighet og mislighold ................................................................ 9

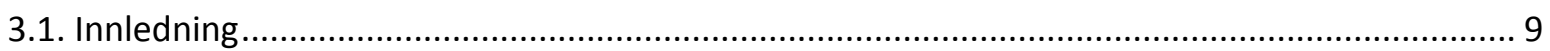

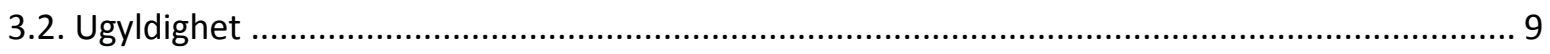

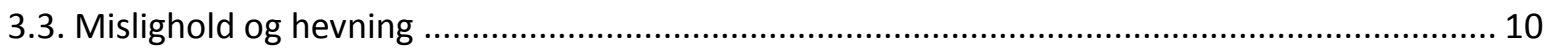

4. Tilbakeføring ved erverv i henhold til bindende avtale.................................................................... 11

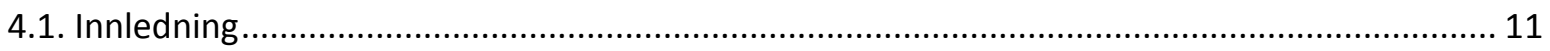

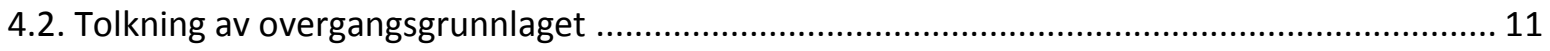

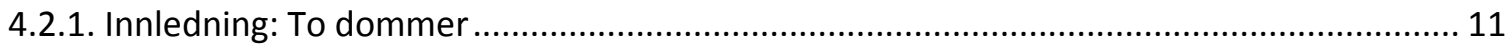

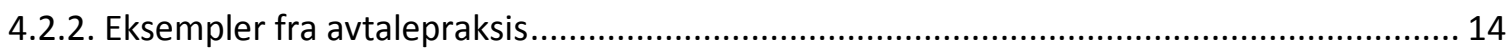

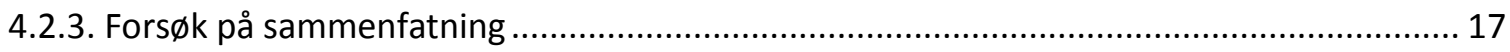

5. Partene: Hvem kan fremme krav overfor hvem? .......................................................................... 18 
5.1. Innledning.

5.2. Avhender som kravshaver

5.3. Motpart

5.4. Kravsfremsettelse 20

6. Bortfall av tilbakeføringsretten ... 20

6.1. Innledning 20

6.2. Kravsfremsettelse innen rimelig tid?

6.3. Er løsningsrettsloven av betydning?

6.4. Kan et tilbakeføringskrav foreldes etter reglene i foreldelsesloven?

6.5. Kan tilbakeføringsretten gå tapt ved ekstinksjon?....

\section{Innledning \\ 1.1. Temaet}

Denne artikkel gjelder eiendomsrett eller rettighet over fast eiendom som er overført fra A til B, og spørsmålet som skal drøftes, er hvorvidt slik overføring blir reversert eller kan kreves reversert når den opprinnelig forutsatte utnyttelse av eiendommen eller rettigheten faller bort eller opphører.

Overføringsgrunnlag som her kan være av interesse for erverv av eiendomsrett, er:

(i) Avtale: Det typiske vil være at A selger fast eiendom til B; det inngås kjøpekontrakt som etterfølges av skjøte. I vår sammenheng er overføring uten vederlag av stor praktisk betydning - en eller flere grunneiere avgir arealer til skole, bedehus, grendehus, veianlegg osv. En viktig undergruppe har vi der tilbakeføring skjer fordi B utnytter en løsningsrett, som i alminnelighet vil ha et eldre avtalegrunnlag.

(ii) Testamentarisk bestemmelse: A har f.eks. bestemt at B skal få en boligtomt.

(iii) Beslutning under skifteoppgjør: Det kan være tingrettens beslutning om B's overtagelse av avdødes hytteeiendom, eller det kan være loddeiernes avgjørelse om at B skal få overta boets faste eiendom.

(iv) Ekspropriasjon: Det er besluttet og gjennomført at A avstår grunnarealer til B. Ofte er muligheten for ekspropriasjon tilstrekkelig 
slik at det blir inngått avtale som overflødiggjør den formelle ekspropriasjon. ${ }^{1}$

(v) Erverv i kraft av odelsrett: Odelseiendommen er ervervet av A som ikke har odelsrett eller har dårligere odelsprioritet enn B, og B løser eiendommen ved en formell odelsløsningsprosess, eller det inngås avtale om dette mellom A og B etter at løsningskrav er fremmet - på lignende vis som ved ekspropriasjon.

For rettigheter over fast eiendom kan det være på tilsvarende vis.

I det følgende er det især eiendomsrett det dreier seg om - og ikke minst: Det er erverv som utspringer av avtale eller testament som skal omtales, men ikke utelukkende, idet de problemer og løsninger man møter ved andre ervervsgrunnlag, i noen utstrekning vil kunne kaste lys over vårt tema.

Ved de skisserte erverv kan det være mer eller mindre klart angitt hvilket formål ervervet skal tjene, og temaet blir hvorvidt bortfall av en forutsatt utnyttelsesmåte kan gi opphav til et reverseringskrav. Det kan være A (som her betegnes som avhender uten hensyn til grunnlaget) som fremsetter krav overfor $\mathrm{B}$ (som her betegnes som erverver), men vi må også ta $\mathrm{i}$ betraktning deres suksessorer: Den rett som B har ervervet, kan i alminnelighet overføres; og den posisjon som A hadde, kan være videreført.

For undergruppe (i) og (ii) kan det i endel tilfeller melde seg spørsmål om det er blitt etablert en stiftelse, altså en selveiende rettighetshaver, jf. definisjonen i stiftelsesl. (lov 59/2001) § 2. Om disse grensespørsmål, se Knudsen \& Woxholth, Stiftelsesloven (2004) s. 26 flg., især s. 45-47.

\subsection{Utgangspunkter}

Det sikre utgangspunktet er at når en eiendoms- eller rettighetsoverføring er gjennomført, er den definitiv. Skal erververen - eller dennes suksessor - måtte gi fra seg det ervervede, må det foreligge særlige omstendigheter. Slike særlige omstendigheter kan være et klart forbehold i overdragelsesavtale eller testament - eller i et ekspropriasjonsvedtak - om at tilbakeføring skal skje eller kan kreves dersom utnyttelsen ikke samsvarer med det som er nærmere angitt. Er det f.eks. sagt at den faste eiendom skal tilbakeføres etter 20 år eller når skolevirksomheten opphører, er det greit, bortsett fra at tilbakeføringsprosedyren

\footnotetext{
${ }^{1}$ Især i vassdragslovgivningen møter vi begrepet hjemfallsrett: Etter en viss tid må rettighetshaveren gi fra seg sin rett, men her dreier det seg ikke om tilbakeføring, men overføring til staten. Uttrykket hjemfall er derfor misvisende.
} 
og eventuelt oppgjør for forbedringer/påkostninger eller forhold som har redusert verdien, kanskje ikke er tilfredsstillende regulert.

\subsection{Den videre fremstilling}

Hovedspørsmålet blir naturligvis om det foreligger grunnlag for tilbakeføring. Besvares dette bekreftende, melder det seg nye spørsmål om gjennomføringen.

Spørsmålene er mange, og den foreliggende lovgivning gir bare i liten utstrekning svar eller veiledning. Rettspraksis er beskjeden, og teoriens bidrag er heller ikke markant. På noen felter er imidlertid reglene klarere, og derfor er det hensiktsmessig først i pkt. 2 å gi en kort oversikt over noen av dem - med sikte på hvorvidt regelverket der har overføringsverdi til det som er vårt hovedtema.

Ved drøftelsen av de avtalebaserte forhold gis det først i pkt. 3 en oversikt over tilbakeføring ved ugyldighet eller mislighold, før det i pkt. 4 gripes fatt i hovedspørsmålet om det for øvrig foreligger tilbakeføringsgrunnlag.

Partsforhold og kravsfremsettelse, som omtales i pkt. 5, etterfølges av pkt. 6 om bortfall av tilbakeføringsretten og pkt. 7 om gjennomføring og oppgjør.

\section{Tilbakeføringsgrunnlag - noen typetilfeller}

\subsection{Ekspropriasjon}

Det første av de områder hvor reglene kan tenkes å være av interesse for vårt tema, er ekspropriasjon. Et slikt erverv skjer for et bestemt formål, jf. oreigningsl. (lov 23. oktober 1959 nr. 3) § 2, og dermed er det nærliggende å spørre om ekspropriasjonservervet skal omgjøres - eller kan kreves omgjort dersom det viser seg at eiendommen eller rettigheten ikke blir utnyttet slik som forutsatt. Svaret har vært omdiskutert, se således Schjødt, Norsk ekspropriasjonsrett (1947) s. 286 flg. og Keiserud \& Bjella, Oreigningsloven (3. utg. 2015) s. 129.

I forarbeidene til oreigningsloven ble emnet drøftet, og konklusjonen i Ot.prp. nr. 43 (1957) s. 87 er klar: At et anlegg

«nedlegges har i seg selv ingen betydning for spørsmålet om eiendommen skal gå tilbake til ekspropriaten. For dette må det kreves et sarskilt grunnlag, f.eks. at ekspropriasjonstiltaket innstilles fordi ekspropriasjonen har vært tidsbegrenset. Men da følger det av seg selv at ekspropriaten igjen får full rådighet over sin eiendom» (min kursivering).

Vilkårsreglene gir her et eksempel på «særskilt grunnlag», jf. oreigningsl. § 10. Er det for vedtak om eller samtykke til ekspropriasjon satt vilkår som skal være oppfylt innen en angitt frist (første ledd), kan ikke-oppfyllelse føre til at 
ekspropriaten kan kreve at inngrepet blir omgjort (annet ledd), jf. Ot.prp. nr. 43 (1957) s. 37:

«Bestemmelsen i § 10 annet ledd som i visse tilfelle gir den tidligere eier rett til å få eiendommen tilbake, gjelder ... bare når det er satt som vilkår at eiendommen skal nyttes på en bestemt måte innen en fastsatt frist. Lenger bør man neppe gå. En ubetinget regel om gjenervervelsesrett hvis eksproprianten ikke bruker eiendommen slik som forutsatt, vil kunne skape vanskeligheter i praksis, således når det gjelder spørsmålet om hvor lang tid som må være forløpet før den tidligere eier kan gjøre noen rett gjeldende.» ${ }^{2}$

Kravet fremsettes overfor departementet (annet ledd siste punktum), og blir det tatt til følge, gir annet ledd første og annet punktum anvisning på et $\varnothing$ konomisk oppgjør; oppgjørsreglene kommer vi tilbake til i pkt. $7 .^{3}$

\subsection{Frigjøring av grunn ved veiomlegging}

Ny vei eller omlegging/utbedring av gammel vei kan føre til at større eller mindre arealer friststilles og kan tenkes anvendt for andre formål. Hvem som da er berettiget til å utnytte den gamle veigrunn, har utløst adskillig debatt - med det grunnleggende spørsmål: Har den som har avgitt grunn til offentlig vei, krav på å få veigrunnen tilbakeført til seg? ${ }^{4}$

Diskusjonen har især vært knyttet til forståelsen av veiloven $1912 \S 8$ der de tre første ledd lød:

«Finder amtsveistyret, efterat herredsstyret har uttalt sig, at en vei, som nedlægges, helt eller delvis er paakrævet som fremkomstvei, blir veien eller en nærmere bestemt del av denne at utlægge til almindelig bruk for de interesserte efter herredsstyrets nærmere bestemmelse.

Hvis dette ikke sker, kommer, forsaavidt ny vei anlægges, værdien av den gamle veigrund til avdrag i erstatningen for grundavstaaelse til det nye veianlæg over samme eiendom efter et ved overenskomst eller skjøn bestemt beløp.

Nedlagt vei, som ikke utlægges til almindelig bruk, og som heller ikke kommer til avdrag i anledning av nyt veianlæg, bør herredsstyret - uten eller mot vederlag overdra til den eller de eiendomme, som støter til veien. Eieren av disse eiendomme kan forlange veigrunden avstaat mot godtgjørelse, bestemt ved skjøn.»

\footnotetext{
${ }^{2}$ Til illustrasjon, se Rt. 1938 s. 468 om eiendom som i 1917 var ekspropriert for oppføring av skolebygning, og som i 1935 krevdes tilbakeført fordi ingen skolebygning var reist og området var omdisponert for boligformål: «Spørsmålet blir da om den omstendighet at eiendommene blev ekspropriert til opførelse av en skolebygning, i og for sig medfører at en anvendelse av dem til boligbygging blir rettsstridig. Dette spørsmål må efter Høiesteretts mening besvares benektende.»

${ }^{3}$ Nærmere om oreigningsl. § 10, se Keiserud \& Bjella, op. cit. s. $124 \mathrm{flg}$.

${ }^{4}$ Se især Otto Arnulf, Eiendomsretten til gamle veger, Norsk Vegmuseums årbok 1993 s. 64-70, Ole Fredrik Melleby, Hvem eier grunnen etter nedlagt offentlig vei? Norsk Vegmuseums årbok 2005 s. 27-60, Otto Arnulf, Allmennhetens ferdselsrett og eiendomsretten til nedlagt offentlig veg, Norsk Vegmuseums årbok $2006 \mathrm{~s}$. 121-126 og Birgitte Akerhaugen, Gamle veger og eiendomsrett, Norsk Vegmuseums årbok 2016 s. 25-57.
} 
I annet ledd lå det altså en forutsetning om at det offentlige var eier ${ }^{5}$ av veigrunnen, ${ }^{6}$ slik at det offentlige derfor kunne disponere over den frigjorte grunn - med mulighet etter første ledd til utlegning «til almindelig bruk for de interesserte», eller etter tredje ledd til overføring av grunnen til tilstøtende naboeiendom.

Prinsippene er videreført i veil. 1963 (lov 21. juni 1963 nr. 23) § 8. Her er det tilstrekkelig å gjengi fra Ot.prp. nr. 60 (1994-95) s. 5:

«Første og annet ledd tar sikte på å sikre veggrunnen til vegformål. Slik bruk vil være i samsvar med og innenfor rammen av veglovens ekspropriasjonsbestemmelser. Tredje ledd regulerer hvordan man skal forholde seg dersom det ikke er aktuelt å nytte den nedlagte veggrunnen til vegformål. Eiere av tilstøtende områder har da rett til å få veggrunnen lagt til sin eiendom. Opprinnelig er veggrunnen vanligvis ekspropriert/ervervet fra nettopp eierne av tilstøtende områder, og det er rimelig at den nedlagte veggrunnen tilbakeføres til dem når den ikke lenger er aktuell til vegformål» (min kursivering).

Det vesentlige i vår sammenheng er at der veigrunn som er offentlig eiet, frigjøres ved nedlegging av vei, kan det offentlige bestemme annen bruk innenfor de rammer som angis i § 8 første ledd (om utlegging til «føremon for ferdsla eller dei vegfarande») og annet ledd (utlegging «til bruk som privat veg»). Utenfor disse tilfellene har tilstøtende grunneier et krav på å få eiendommen overført til seg mot vederlag. Hvorvidt han (eller hans forgjenger) $i$ sin tid avstod eller måtte avstå grunn til veien, er ikke tillagt noen betydning.

\subsection{Landbruk og odelsrett}

\subsubsection{Odelsmisbruk og «klårt urimeleg» løsningskrav}

Sterkt forenklet innebærer odelsretten sikring av at en landbrukseiendom fortsatt skal kunne drives av samme slekt, med et prioritetssystem for slektsmedlemmene: Den (bedre) odelsberettigede kan løse (tvangserverve) eiendommen fra den som ikke har odelsrett eller har odelsrett med lavere prioritet. Når en eiendom er ervervet i kraft av odelsrett, kan det tenkes at forutsetningene for bruken av retten viser seg å svikte, men det kan også bli fremsatt innsigelser av slik art allerede idet odelsretten gjøres gjeldende. Det er her læren om odelsmisbruk kan bli påberopt. ${ }^{7}$

\footnotetext{
${ }^{5}$ Om forståelsen av hva som i denne sammenheng ligger i eiendomsrett, har det vært diskusjon, se foregående note.

${ }^{6}$ Jf. også veil. $1912 \S 26$ fjerde ledd: «Ved nedlæggelse av offentlig vei blir, forsaavidt angaar de i $§ 12$ a nævnte veier, staten og for andre veiers vedkommende herredskommunen at betragte som eier av grunden, medmindre der angaaende denne er truffet bestemmelse med hjemmel av $\S 8$, første, jfr. sidste led.»Veier omhandlet i $\S 12$ a var de som «baade er anlagt og som vedlikeholdes udelukkende eller væsentligst for statens regning».

${ }^{7}$ Se nærmere Rygg, Skarpnes \& Falkanger, Odelsloven (5. utg. 2011) s. 101-105.
} 
Denne misligholdslære, som er utviklet gjennom rettspraksis, innebærer at et løsningskrav ikke blir godtatt dersom løsning må ansees som «misbruk av odelsretten». Et klart eksempel gir Rt. 1988 s. 56: A - av norsk avstamning, bosatt i USA i hele sitt liv - ble nektet å løse en gård som hans bestefar hadde eiet til han døde i 1953. Høyesterett uttalte at en odelsløser ikke kan kreve å få sine anførsler om hensikten med løsningen lagt til grunn «dersom de ikke kan tåle en konfrontasjon med de reelle forhold i og omkring søksmålet». I prinsippet må misbrukssynspunkter kunne begrunne en reversering av en gjennomført løsning. ${ }^{8}$

Beslektet med misbrukslæren er regler vi finner i odelsl. (lov 58/1974) $\S 21 \mathrm{om}$ «løysingsnekt når samtykke til løysing vil vere klårt urimeleg». ${ }^{9}$

\subsubsection{Misligholdt bo- og driveplikt $t^{10}$}

Den odelsberettigede har boplikt i fem år etter overtagelsen av eiendommen, jf. konsesjonsl. (lov 98/2003) $§ 5$ annet ledd og har dessuten (som alle eiere av jordbruksjord) tidsubegrenset driveplikt etter jordl. (lov 23/1995) § 8. Odelsl. $\S 28$ sanksjonerer brudd på boplikten og brudd på driveplikten som skjer de første fem år etter overtagelse i medhold av odelsrett. Første ledd gir andre odelsberettigede - også de med svakere prioritet - rett til å gå til løsningssak mot den misligholdende eier. Har misligholderen fått eiendommen gjennom et odelssøksmål, gir annet ledd også den odelsløse saksøkte en etterstilt rett til å «søkje eigedomen tilbake». Det skjer etter odelsløsningsreglene «så langt dei høver» (§ 76), med erleggelse av en løsningssum som blir fastsatt ved odelstakst, jf. odelsl. $\S 66$. I annet ledd-tilfellet kan det i tillegg komme på tale med erstatning, jf. $\S 58 .{ }^{11}$

\subsubsection{Etteroppgjør $\mathrm{r}^{12}$}

En odels- eller åsetesberettiget overtar ofte eiendommen til en gunstig pris især der overtageren kan påberope seg åsetesrett: Overtageren skal ikke bli så hårdt gjeldsbelastet at han ikke kan drive eiendommen på forsvarlig vis. Tingene kan imidlertid utvikle seg annerledes enn forutsatt, og odelsl. $§ 57$ har regler om at der overtageren i løpet av de første 10 år gjør «ein monaleg vinst» - typisk

\footnotetext{
${ }^{8}$ Den A som har tapt i en løsningssak med B, vil nok i alminnelighet ha små sjanser til å vinne frem på grunn av rettskraftsvirkninger, men det kan jo være andre odelsberettigede som har holdt seg tilbake fordi B fremstod som løsningsberettiget.

${ }^{9}$ Se nærmere Rygg, Skarpnes \& Falkanger, op. cit. s. 124 flg.

${ }^{10}$ Se nærmere Rygg, Skarpnes \& Falkanger, op .cit. s. 163-168.

${ }^{11}$ Annet ledd gjelder også der løsningsmannen (saksøkeren) overdrar eller bortleier eiendommen i løpet av de første fem år.

${ }^{12}$ Se nærmere Rygg, Skarpnes \& Falkanger, op. cit. s. 260-270.
} 
ved salg eller ved å bli utsatt for ekspropriasjon - skal det skje et pengemessig etteroppgjør.

\subsection{Omdanning etter stiftelsesl. § 55}

Stiftelsesl. kap. 6 har regler om omdanning av stiftelser, men etter $\S 55$ kan det skje omdanning av annet enn stiftelser - med tilsvarende anvendelse av de øvrige regler kap. $6 .{ }^{13}$ Det nærmere anvendelsesområde for $\S 55$ er formuesverdier som er gitt til en eller flere «rettssubjekter» (bokstav a), og midler innsamlet for et bestemt formål (bokstav b). Omdanning i medhold av $\S 55$ kan også skje for foreningsmidler når foreningen praktisk sett er opphørt å virke (bokstav c).

Hva omdanning innebærer, er angitt i $§ 45$, jf. de ganske strenge vilkår for omdanning i § 46. I vår sammenheng er det tilstrekkelig å gjengi fra $§ 45$ første ledd om at omdanning kan innebære «endring eller opphevelse av den rettslige disposisjonen som danner grunnlaget for stiftelsen, eller av stiftelsens vedtekter». ${ }^{14}$ Her er m.a.o. hjemmel for å endre de rådighetsbegrensninger som f.eks. måtte ligge i A's gave til B. I alminnelighet vil omdanning her dreie seg om endret bruk og/eller overføring til annen begunstiget. Ordet «opphevelse» i $\S 55$ kunne tyde på at selve disposisjonen kan oppheves med den følge at eiendommen går tilbake til avhenderen. Slik skal det ikke forstås; det kan bli tale om opphevelse av f.eks. et pålegg om hvorledes eiendommen skal brukes.

Dreier det seg om servituttverdier som fanges opp av servituttloven (lov 29. november 1968), er man imidlertid henvist til omdannings- og avskipingsreglene i servituttl. $\S \S 5-8 .{ }^{15}$

\subsection{Jordskifte}

Jordskifte innebærer omstrukturering av fast eiendom, herunder beslutninger om opphør av begrensede rettigheter og om nødvendig: etablering av nye slike.

Noen tilbakeføring blir det ikke tale om. Det blir i tilfelle helt tilfeldig: Et areal som i sin tid ble overført fra eiendom $\mathrm{x}$ til eiendom $\mathrm{y}$, kan med de nye, rasjonelle grenser tenkes å komme tilbake til x, eller til en helt annen eiendom $\mathrm{z}$.

\subsection{Sammenfatning vedrørende pkt. 2.2 til 2.5}

De tilfeller som det nå er gitt en oversikt over, etterlater ikke noe helhetlig bilde. Det kan imidlertid pekes på følgende:

(i) Tilbakeføring er i ekspropriasjonstilfelle et unntak (oreigningsl. § 10). Ved veinedlegging kan grunn bli overført fra det offentlige til private, men dette

\footnotetext{
${ }^{13}$ Se nærmere Knudsen \& Woxholth, op. cit. s. 252 flg.

${ }^{14} \mathrm{Om} \S 45$, se nærmere Knudsen \& Woxholth, op. cit. s. $200 \mathrm{flg}$.

${ }^{15}$ Om disse, se Falkanger \& Falkanger, Tingsrett (8. utg. 2016) s. 234-242.
} 
er ikke nødvendigvis en tilbakeføring; overføring til tilstøtende eiendom er ikke nødvendigvis til den eiendom som i sin tid avgav veigrunn. Ved misligholdt boog driveplikt for odelseiendom kan det bli tale om tilbakeføring.

(ii) Etteroppgjørsreglene i odelsl. § 57 gir en mellomløsning:

Eiendomsovergangen blir ikke reversert, men det blir et $\varnothing$ konomisk etteroppgjør.

(iii) Der det foreligger endringsgrunnlag, kan det være opprinnelig eier (eller dennes suksessor) som er berettiget, men det kan være flere (odelsl. § 28) eller andre (veil. § 8).

(iv) Ved ekspropriasjon trekkes myndighetssiden inn, mens det i de $\varnothing$ vrige tilfeller vil være rent privatrettslige spørsmål som eventuelt må forfølges ved de ordinære domstoler.

\section{De frivillige overføringer - ugyldighet og mislighold}

\subsection{Innledning}

Ved en frivillig overføring av eiendomsrett til fast eiendom kan et krav om tilbakeføring springe ut av de alminnelig regler om ugyldighet og mislighold. Det er derfor naturlig med en omtale av disse regelsett og deres forhold til det som er det typiske for vårt undersøkelsesområde, nemlig at tilbakeføringsspørsmålet melder seg adskillig tid etter at ervervet er gjennomført: besittelsen er for lengst overført, og skjøte er utstedt. Svaret på våre tilbakeføringsspørsmål (jf. pkt. 4) vil bero på tolkning av overføringsgrunnlag, supplert med hva som kan utledes av etterfølgende omstendigheter og mer generell forutsetningslære.

\subsection{Ugyldighet}

Etter at B har overtatt eiendommen, kan det bli fremsatt ugyldighetsinnsigelser. Her kan det tenkes at det fra den krenkedes side foreligger ratihabisjon eller at innsigelsen er tapt på grunn av passivitet; ofte kan nok disse alternativer gli over i hverandre. Hovedregelen er imidlertid at der det foreligger ugyldighet, gir det rett til å kreve tilbakeføring: ${ }^{16} \mathrm{Er}$ det avhender som påberoper ugyldighet, skal eiendommen tilbakeføres til ham, og kjøpesummen skal tilbakeføres til erververen. Der det er erververen som påberoper seg ugyldighet, blir det krav om å få kjøpesummen tilbake mot at eiendommen stilles til disposisjon.

\footnotetext{
${ }^{16}$ Ugyldighet og dermed evt. krav om tilbakeføring medfører ikke at kravet faller inn under løsningsrettsloven (lov 64/1996); her står vi overfor spørsmål som må løses etter de regler som gjelder for ugyldige avtaler, se f.eks. Lilleholt, Kontraktsrett og obligasjonsrett (2017) s. 464-471. Reglene er usikre. Er det en verdidifferanse, bør den part som ikke var i god tro «gjera opp for verdidifferansen» (s. 469), og den som har vært i ond tro, må gi fra seg avkastningen, mens dette er mer tvilsomt i god tro-tilfellene (s. 470).
} 
I den videre fremstilling forutsettes det at overføringsgrunnlaget ikke kan angripes etter ugyldighetsreglene. Reglene for så vidt kan imidlertid ha sin interesse når tilbakeføring foranlediger spørsmål om oppgjør vedrørende verdistigninger og verditap.

\subsection{Mislighold og hevning}

Av interesse i vår sammenheng er påberopelse av misligholdsregler etter at eiendommen er overført til erververen. Kan det i så fall bli tale om tilbakeføring?

Her møter vi prinsippet i avhendingsl. (lov 93/1992) § 5-3 fjerde ledd:

«Seljaren kan ikkje heve etter at skøyte er tinglyst eller gitt kjøparen, eller kjøparen har overteke bruken av eigedomen, med mindre det gjeld brot på avtale om naturalyting, husvære eller liknande personleg rett som kjøparen måtte vite hadde særleg vekt for seljaren. Hevingsretten står og ved lag om seljaren har teke atterhald om det, eller kjøparen ikkje held fast ved avtala.»

Overtagelse av eiendommen avskjærer således i prinsippet avhenders hevningsmulighet. ${ }^{17}$ At kjøperen f.eks. ikke betaler avdrag på kjøpesummen, gir ikke hevningsrett - med mindre kjøperen godtar et tilbakeføringskrav. Det er ytterligere to unntak. Det første gjelder visse personlige naturalrettigheter typisk: mislighold av en kåravtale kan berettige til hevning. Det annet er at det på forhånd er avtalt eller forbeholdt hevningsrett, f.eks. at x dagers forsinkelse med betaling av en kjøpesumstermin som forfaller etter overtagelsen, er hevningsgrunnlag. Et annet eksempel er at avtalen har bestemmelser om en viss bruk, eller om at eiendommen ikke kan utnyttes på en bestemt måte (f.eks. villaklausul eller lignende negativ servitutt). Et hevningsforbehold kan være knyttet også til slike bestemmelser, men er det ikke tatt et rimelig klart hevningsforbehold, skal det meget til før en hevning med tilbakeføringsrett kan innfortolkes. ${ }^{18}$

Også mulig tilbakeføring på slikt grunnlag ligger utenfor hva som her skal tas opp. ${ }^{19}$ Men grensen mislighold/bristende forutsetninger kan være subtil, jf. Augdahl, Den norske obligasjonsretts almindelig del (5. utg. 1978) s. 168-170 og Hagstrøm, Obligasjonsrett (2. utg. 2011) s. 336-338. Det skal ikke gås nærmere inn på hva som i bunn og grunn er spørsmål om terminologi; det er tilstrekkelig å bemerke at med sikte på vårt undersøkelsesfelt kan det undertiden

\footnotetext{
${ }^{17}$ Noen tilsvarende begrensning har vi ikke for kjøperen, jf. avhendingsl. § 4-13.

${ }^{18}$ Det må gjelde selv om det, som hevdet, godtas at det legislative grunnlag for hevningsavskjæringen er svakt fundert. Til drøftelsen om det legislative grunnlag, se f.eks. Bergsåker, Kjøp av fast eiendom (5. utg. 2013) s. 481 flg.

${ }^{19}$ Som for ugyldighetstilfellene vil et krav om tilbakeføring ligge utenfor løsningsrettsloven; om oppgjøret ved tilbakeføring, se Lilleholt, op. cit. s. 316-322 - med følgende prinsipper: Ikke ansvar for «verdireduksjon på grunn av bruk i god tru med vanleg aktsemd » (s. 317), med godskrivning av «avkasting av ytinga og vederlag for bruken» (s. 318).
} 
fremstå som vilkårlig hvorvidt en bestemt bruk av en ervervet eiendom må innfortolkes (anses å ligge) i avtalen, eller skal baseres på «en relevant forutsetning».

\section{Tilbakeføring ved erverv $i$ henhold til bindende avtale \\ 4.1. Innledning}

I overføringsgrunnlaget kan det være satt klare grenser for utnyttelsen av eiendommen. Enklest er det med tidsbegrensninger: Eiendommen kan utnyttes i f.eks. 20 år. Her kan det spørres om erverver B har fått en eiendomsrett eller en omfattende bruksrett. Svaret er i vår sammenheng først og fremst av terminologisk karakter, idet realiteten klarligvis er at B's befatning med eiendommen opphører etter 20 år; nå får $\mathrm{A}$ full rådighet - og det må gjelde selv om avtalen ikke gir regler om tilbakeføring. Det kan nok bli strid om når tiden begynte å dreie og dermed om når utløpstidspunktet kommer, men dét lar vi ligge. En annen form for begrensning har vi der bruken av eiendommen er angitt, f.eks. til skole eller ungdomshus. Er det angitt at eiendommen skal gå tilbake til A der slik bruk opphører, kan man få diskusjon om det foreligger «opphør», men også dette er utenfor det som skal omtales nærmere. Derimot, at vi her kan få tvist ved gjennomføringen av tilbakeføringen, er viktig, og vi kommer til det i pkt. 7. Hvis det bare er sagt at det er tomt for skole som overføres - uten at det er noe om tilbakeføring - møter vi de problemer som omtales her i pkt. 4.

Når det i det etterfølgende sies meget som kan kaste tvil over tilbakeføringskrav, må det ikke glemmes at det finnes et stort antall tilfeller der tilbakeføring har vært uproblematisk. Det kan være enkle tilfeller: Grunneieren har stilt tomt til rådighet for en hytte, som har vært disponert av en person eller en forening. Når strøket utvikler seg slik at utnyttelse for fritidsformål ikke lenger er aktuelt, må vi tro at rådigheten oftest er gått tilbake til grunneieren uten at rettsvesenet er blitt trukket inn. Og det vil vi tro er skjedd også i litt mer avanserte tilfeller. Videre minnes det om det som er sagt ovenfor i pkt. $2.3 \mathrm{om}$ lovreguleringen der veigrunn frigjøres: Det er ikke slik at det offentlige fritt kan disponere over slike arealer.

\subsection{Tolkning av overgangsgrunnlaget \\ 4.2.1. Innledning: To dommer}

Her i pkt. 4.2.1 skal det redegjøres for to dommer fra slutten av 1930-tallet før endel andre avtalereguleringer nevnes med påpekning av de tolkningsproblemer 
som kan oppstå. I pkt. 4.2.3 gjøres et forsøk på å trekke ut noen viktigere momenter ved tolkningen av om det foreligger tilbakeføringsplikt.

Rt. 1936 s. 697 (Holmestrand): Da det i 1890-årene ble aktuelt å flytte Asker Seminar (lærerskole), kom Holmestrand på tale som nytt lærerskolested. Kommunestyret i Holmestrand fattet vedtak om å kjøpe eiendommen Nedre Gausen og tilby lærerskolen «fri grunn inntil 200 aar (20 maal)», koblet med at folkeskolen skulle flyttes i nærheten. Da staten sa ja, solgte kommunen hovedbygningen på Nedre Gausen til staten for kr. 20.000. Flyttingen ble gjennomført; staten bygget for lærerskolen, og kommunen oppførte ny bygning for folke- og middelskole. I 1931 ble det imidlertid besluttet å nedlegge lærerskolen, og skolebygningen skulle nå tas i bruk som døveskole.

Kommunen protesterte: Tilbudet i 1896 var betinget av at lærerskolen ikke bare flyttet til Holmestrand, men at den ble der så lenge staten holdt lærerskoler, eller iallfall mer enn 30 år. Her hadde staten kontraktsmessig bundet seg til denne betingelse. Kontrakten ble brutt ved nedleggelsen av lærerskolen, og staten pliktet derfor å betale erstatning. Subsidiært ble det hevdet at staten var forpliktet til helt eller delvis å gjenopprette forholdet som det var før kontrakten, dvs. at staten helt eller delvis måtte dekke kommunens store økonomiske ofre $\mathrm{i}$ forbindelse med flyttingen av lærerskolen. Atter subsidiært ble det påstått at staten pliktet å tilbakeskjøte hovedbygningen på Nedre Gausen og den gratis tildelte vel 20 dekar store tomt som var overlatt staten til et bestemt formål, nemlig lærerskole. Kommunen ville i så fall tilbakebetale de kr 20.000 som staten i sin tid hadde betalt for hovedbygningen.

Byretten, som Høyesterett «i alt vesentlig» sluttet seg til, uttalte:

«Det maa ansees som en selvfølge at flytningen maatte være en virkelig flytning med en oprettelse av lærerskole i Holmestrand, ikke blott noget rent pro forma og nedleggelse med engang. Paa den annen side maa det ansees som en selvfølge at Staten ikke bandt sig til for alltid eller til for saa lang tid som den holder lærerskoler da at ha en i Holmestrand. Og Holmestrand kommune har hatt fordel av lærerskolen som tilsiktet i de 30 aar den har bestaatt. Det er mulig dette er en kort tid for en lærerskole, og under hensyn til de store økonomiske ofre som blev tatt fra kommunens side og ogsaa fra Statens side, har forventningene saavel fra Holmestrands som Statens side formentlig vært at at skolen skulde drives lenger. Men disse forventninger blir ikke derfor kontraktsvilkaar, og retten finner ikke berettigelse til at innfortolke i beslutningen av 1896 nogen garanti eller forpliktelse for Staten til at holde skolen igang i lengere tid ... Begge parter gikk ut fra at naar lærerskolen først blev bygget, vilde den bli nogen tid, uten at det blev gjort til nogen juridisk forpliktelse at den skulde bli over 30 aar. Og er der om dette siste tvil maa det gaa ut over den som krever erstatning m.v., Holmestrand kommune» (mine kursiveringer). 
Dermed ble det heller ikke funnet grunnlag for noen tilbakeføring: Det kunne ikke

«... ansees som en forutsetning at Staten naar lærerskolen blev nedlagt skulde skjøte tilbake hovedbygningen paa Nedre Gausen og omliggende grunn. Staten fikk dette billig ... Men paa tomten er senere overensstemmende med forutsetningene lærerskolen bygget, og det maa ansees som en forutsetning at det hele er tilskjøtet Staten endelig. Tilbakeskjøtning av bygningen alene er ikke paastaatt.»

Og endelig:

«Det kan heller ikke ansees som stridende mot forutsetningene at Staten naar lærerskolen blev nedlagt og skolebygningen blev ledig, anvender den til offentlig døveskole.»

Den annen dom finnes i Rt. 1939 s. 926 Agder (Hesnes tuberkulosehjem): En barnløs, sterkt kristelig engasjert lærerinne gav i 1924 eiendommen Hesnes for formål som lagmannsretten sammenfattet slik:

« ... eiendommen skal benyttes til tuberkulosehjem, hvor fattige syke skal bli mottatt for å søke helbredelse gjennom bønn. Henvisningen til skriftstedet [Math. 10-7-10] ${ }^{20}$ tyder på at forutsetningen har vært at alt skal ydes gratis. Men det kan neppe ansees bindende pålagt gavemottagerne at det ikke må tas betaling for selve opholdet, hvis det måtte vise sig nødvendig ... for å kunne holde driften gående».

Mottager var to «evangelister» som på forhånd hadde ivret sterkt for etablering av en slik institusjon.

Da virksomheten ble endret til «et hotell med pensjonspriser 5-8 kroner», eller som det også ble sagt: «et kristelig betonet gjestested» - riktignok med virksomheten fra en annen eiendom enn den gavebrevet gjaldt - hevdet giverens arving i henhold til testament at eiendommen måtte tilfalle henne. Og det fikk hun medhold i. Selv om det skulle være vanskelig eller umulig med drift etter de opprinnelig forutsetninger, kunne dette, etter «klausulens rettslige natur», ikke føre til at formålet ikke lenger gjaldt. Innsigelser om at krav om legetilsyn og sviktende gavetilstrømning tilsa bruksendringen, ble det pga. bevissituasjonen ikke tatt hensyn til. Uten at det var avgjørende for utfallet, gav én dommer uttrykk for «tvil om det var en bindende forutsetning for gaven at den skulde anvendes nettop til tuberkulosehjem». ${ }^{21}$

\footnotetext{
${ }^{20}$ «Og når I går avsted, da forkynn dette budskap: Himlens rike er kommet nær! Helbred syke, oppvekk døde, rens spedalske, driv ut onde ånder! For intet har I fått det, for intet skal I gi det. I skal ikke ta gull eller sølv eller kobber med i eders belter, ikke skreppe til reisen, ikke to kjortler, ikke sko, ikke stav; for arbeideren er sin føde verd.»

${ }^{2121}$ I dag vil nok denne tvisten ha funnet sin løsning ved at driveren hadde begjært omdanning etter stiftelsesl. kap. 6.
} 


\subsubsection{Eksempler fra avtalepraksis}

De bestemmelser som forekommer i praksis - i gjensidige avtaler eller i gavetilsagn - varierer sterkt med hensyn til objekt- og formålsbeskrivelse.

Meget blir dermed overlatt til en vanskelig tolkning der ordlyden isolert sett ikke gir noe entydig svar. Når man i slike tilfeller skal se hen til de nærmere omstendigheter på disposisjonstidspunktet, ${ }^{22}$ kan det være slik at dette ligger så langt tilbake i tid at det må konstateres at pålitelig informasjon ikke foreligger. En annen kilde når stiftelsesgrunnlaget skal tolkes, er partenes etterfølgende adferd. Også her vil informasjonen kunne være mangelfull og usikker.

At avgjørelsen av et tilbakeføringskrav kan være problematisk - ikke minst når krav fremsettes etter mange år - kan belyses ved noen, litt tilfeldig valgte klausuler.

På noen områder har det dreid seg om så vidt mange tilfeller av grunneller rettighetsavståelse at det er utviklet standard avståelseserklæringer. Eksempler har vi vedrørende avståelse av grunn til vei og til havner. Om veiavståelse, se foran i pkt. 2.2. Her skal nevnes noen eksempler fra avståelse av grunn til havner. For så vidt må bakgrunnen kort skisseres:

Opp gjennom årene er det etablert mange hundre statlig eide fiskerihavner, og til disse er det fra private grunneiere avgitt både grunn og rettigheter. Formelt er dette skjedd vederlagsfritt fordi man som grunneier på etableringstidspunktet fikk store reelle fordeler - en trygg havn for fiskefartøyer og forenklet transport for personer og varer. I våre dager er disse momenter ikke så viktige (istedenfor fiskefartøyer er det lystbåter som benytter havnen, personog varetransport går på vei), og spørsmålet om tilbakeføring har derfor meldt seg.

Gjennom ca. 100 år (fra 1893 til 1990) er det brukt i alle fall 10 ulike standarderklæringer. Noen formuleringer fra tre forskjellige standardtekster gjengis:

(1) «Uden Betaling at afgive den for Anlægget og dets Udførelse fornødne Grund ...

Foranstaaende Bestemmelse blive, som en paa Eiendommen hvilende stedsevarig Servitut eller Hæftelse, fuldt forbindende for enhver senere Eier eller Bruger ... »

(2) «Vi avstaar fornøden grund til anlægget, dets utførelse og vedlikehold efter de til enhver tid gjældende planer ... »

(3) «Kystverket ... gis en uinnskrenket og stedsevarig bruksrett til den grunn med tilhørende sjøgrunn som er nødvendig til anlegget og dets senere bruk og utnyttelse ... $\gg$

\footnotetext{
${ }^{22}$ Et eksempel på at en tilsynelatende klart tekst, ut fra vidneprov om bakgrunnen, blir kraftig modifisert, gir RG 1996 s. 365 Karmsund.
} 
En rekke tolkningsspørsmål melder seg umiddelbart, men her nøyer vi oss med å peke på det felles trekk: Hva som avgis, kan være uklart, men det som avgis, er i alle fall til beste for anlegget. Og dermed blir spørsmålet i vår sammenheng: Hvorledes forholder man seg når anlegget ikke lenger eksisterer, eller det ikke lenger kan tales om et anlegg slik som man forstod dette uttrykk på avgivelsestiden? Et klart eksempel er fiskerihavnen som er blitt lystbåthavn, naustene er blitt kaféer og fritidsboliger, og det er lenge siden havnen hadde noen kommunikasjonsmessig betydning. Grunnverdiene kan nå være betydelige.

Et eksempel fra rettspraksis - LF-2009-17543 - nevnes nedenfor.

Utenom slike tilfeller med bruk av standarderklæringer finner man i praksis stor variasjon. Noen erklæringer er profesjonelt utformet, med presise angivelser av grenser og utnyttelse, og kanskje også med angivelse av muligheter for endret utnyttelse, eller om tilbakeføring der det forutsatte formål faller bort. Andre kan være ufullstendige eller uklare - nok ofte fordi de personer det gjaldt på stiftelsestiden, var fullt ut enige om grenser og utnyttelsesmåte, men ikke sørget for at dette ble gitt rimelig klar skriftlig form.

Her gjengis til illustrasjon en (av meg noe bearbeidet) erklæring som kan reise en rekke tolkningsspørsmål. Noen av dem kan være av betydning når et tilbakeføringskrav måtte bli fremsatt:

«A gir til evig eie B-forening tomt til forsamlingshus og vedskjul/uthus på eiendom $\mathrm{x}$. Grunnmuren til forsamlingshuset er på plass. Blir det engang behov for en større bygning, har A ikke noe imot det. Skog som er til skade for huset eller tar lyset fra vinduene, kan hugges. Det er fri gang- og kjørevei fra hovedveien til huset.»

Det begynner med «evig eie», men resten av teksten bringer kanskje tanken mer i retning av et punktfeste.

Det vesentlige er om man i de tilfeller som det nå er gitt eksempler på, kan tillate en endret bruk. F.eks.: Det blir sentralskole, skolen på tomten nedlegges, og bygningen tas i bruk som grendehus; men etter hvert nedtrappes også denne virksomhet. Eller: Med endret bygdestruktur er det bedre med foreningshus et annet sted; kan man da selge tomt med hus og bruke pengene til oppføring av lignende hus et annet sted?

Det vi i alle fall kan konstatere, er at dersom formålet antas å sette en grense, vil formålsangivelsen bli tolket «i samsvar med tida og tilhøva» - for å bruke formuleringen i servituttl. (lov 29. november 1968) § 2. I servituttforhold har domstolene som bekjent strukket seg langt i den retning - også før vi fikk servituttloven. Her er det tilstrekkelig å minne om den «dynamiske» tolkning av ferdselsretter, som bl.a. innebærer at ferdselsrett fra før bilismens tid i dag 
omfatter biltrafikk. ${ }^{23}$ I vår sammenheng er her avgjørelsen i Rt. 1976 s. 226 (Stavanger Margarin) av betydelig interesse:

Ved et makeskifte i 1926 hadde kommunen forbeholdt seg å anlegge kai utenfor det som i 1970-årene var Stavanger Margarins eiendom. Da det i 1970årene ble anlagt kai med en 18 meter bred gate mellom kaien og fabrikkens eiendom, hevdet fabrikken bl.a.:

«Det var en forutsetning i 1926 at kai skulle anlegges utenfor Stavanger Smørfabriks eiendommer, og at fabrikkens fordeler av anlegget minst skulle tilsvare de verdier sjøgrunn inntil kote v 2 og tilflottsrett - som fabrikken gav fra seg. Denne forutsetning er ikke oppfylt. Den avståtte sjøgrunn er overhodet ikke anvendt til kaianlegg, men er gått inn i en hovedtrafikkåre som er 18 meter bred, og som ikke innebærer noen verdiøkning for fabrikkens eiendommer» (s. 229).

Høyesterett fant imidlertid at

«klausulen i makeskifteskjøtet må forstås slik at kommunen fikk rett til å oppfylle den sjøgrunn som lå til Stavanger Smørfabriks eiendommer og anlegge kai i samsvar med de krav man på det aktuelle tidspunkt måtte stille til et moderne kaianlegg, uten at det skulle være anledning til en konkret vurdering av fordeler og ulemper for den ene eller annen part. Når anlegg av kai ikke er blitt aktuelt før i 1970-årene, må den kunne anlegges $i$ samsvar med denne tids krav. Om kai var blitt anlagt i 1920-årene, ville grunneieren - etter min mening - ikke kunne ha motsatt seg en senere utbygging for $\stackrel{a}{\circ}$ tilfredsstille dagens krav. Og like lite som Stavanger Margarin A/S ville kunne ha påberopt seg 1920- årenes forutsetninger i forbindelse med slik senere utbygging, mener jeg selskapet kan påberope slike forutsetninger om anlegg først i dag er blitt aktuelt» (s. 229-230, mine kursiveringer).

Dersom man også etter en «dynamisk» tolkning må konstatere at eiendommen ikke brukes i samsvar med formålet, viser Rt. 1936 s. 697 (Holmestrand) omtalt foran i pkt. 4.2.1 - at det er flere omstendigheter som må tas i betraktning før et tilbakeføringskrav kan godtas. Viktige momenter i det tilfellet var tidens gang og de foretatte investeringer som nå kunne nyttiggjøres ved at eiendommen ble tatt i bruk for et annet skoleslag (døveskole).

Jf. også LF-2009-17543 vedrørende småbåtanlegg i fiskerihavnen i Midsund (Ugelvik-saken) der lagmannsretten sa dette om utnyttelse for andre formål:

«Bruksretten staten ervervet i 1967, som medførte millioninvesteringer, var 'uinnskrenket og stedsevarig' hva tvisteområdet gjelder. Selv om behovet for fritidsbåthavn den gang var et helt annet enn nå, måtte partene forutse at havnen med tid og utvikling kunne få en endret utnyttelse. Dette hensyn synes etter lagmannsrettens vurdering også klart ivaretatt ved formuleringen 'senere bruk og utnyttelse'.»

\footnotetext{
${ }^{23}$ Se f.eks. Falkanger \& Falkanger, op. cit. (8. utg. 2016) s. 211-212 og s. 225-227.
} 
En annen innfallsvinkel er å se en formålsforutsetning som en negativ servitutt altså at arealet ikke kan utnyttes for annet enn det som henger sammen med formålet. Og da er det grunn til å minne om at slike begrensninger kan falle bort på grunn av endrede forhold, se især Gjensidige-dommen i Rt. 1995 s. 904:

«Utviklingen i et område kan medføre at en negativ servitutt taper sin betydning og derfor faller bort. Anlegg av motorvei gjennom Sollerudområdet og utvidelsen av denne til 8 kjørefelt, slik at den i dag fremstår som en av våre mest trafikkerte motorveier, har etter min mening på en markant måte atskilt området på sydsiden av veien fra det villastrøk der ankemotpartene har sine eiendommer. Det er ikke lenger snakk om samme strøk. Arealet på sydsiden må vurderes i lys av den øvrige utbyggingen i dette strøket, og på bakgrunn av den sterke innvirkning som motorveien har på miljøet. Boligbygging så nær motorveien som Gjensidigebygget ligger, er i dag uaktuelt, noe utbyggingen langs denne del av Drammensveien viser. Området er preget av kontorbygg og andre næringsbygg. Det må anses som et område hovedsakelig for næringsutbygging, i den utstrekning utbygging tillates. Servituttene har her utspilt sin rolle og må anses bortfalt.»

Senere har Høyesterett begrenset dommens rekkevidde, jf. Rt. 2002 s. 145 (Bortelid) og Rt. 2008 s. 362 (Naturbetong I), men det prinsipielle om at «utviklingen i et område» kan gripe inn, står ved makt. I vår sammenheng er det vesentlig å peke på at dersom det foreligger uberettiget utnyttelse, vil erstatning kunne være en sanksjon, men nabol. § 10 gir etter omstendighetene også rett til «retting» - og det kan være å gå tilbake til opprinnelig bruksutnyttelse.

\subsubsection{Forsøk på sammenfatning}

Med utgangspunkt i det foregående skal det her i pkt. 4.2.3 pekes på noen momenter som kan være av betydning når et tilbakeføringskrav skal vurderes der rettsgrunnlaget ikke er entydig.

Vederlag er åpenbart viktig: Når A overfører en fast eiendom til B mot fullt vederlag, er det lite rimelig å tro at A i tillegg skal ha et tilbakeføringskrav. Et slikt krav må i det minste ha fremkommet noenlunde klart - enten i overføringsdokumentasjonen eller i velfunderte forutsetninger som erververen må antas å ha kjent og ha akseptert (direkte eller stilltiende). Forutsetninger av denne art vil kunne være utsprunget av vern om avhenders interesser knyttet til nærliggende eiendom, og dermed kommer man lett over i naborettslige problemstillinger som antydet ovenfor.

Et vederlag kan anta mange former. Det kan f.eks. oppstå naturalfordeler for avhenderen, og de kan være likeverdige med eller mer verd enn et vanlig pengevederlag. Ved avståelse av grunn til vei eller fiskerihavn har det siste åpenbart ofte vært tilfellet.

Tidsforløpet er et annet viktig stikkord, eller med litt andre ord: «tida og tilhøva» (servituttl. § 2) som uttrykk for at forholdene endrer seg, setter sitt klare 
preg på tolkningen. Basert på resonnementet f.eks. i Rt. 1976 s. 226 må det kunne sies at skal det sees bort fra det dynamiske element, må det ha en rimelig klar forankring i stiftelsesgrunnlaget.

Tidsforløpet vil trolig kunne influere på tolkningen også der forholdene ikke har endret seg synderlig (eller endring i samsvar med «tida og tilhøva» er avtalemessig avskåret). Men vanligvis er nok dette forbundet med et tredje, viktig moment: de investeringer som er foretatt, og den virksomhet som er blitt etablert. Det er åpenbart forskjell mellom tilbakeføring av en tomt med forfallen bebyggelse (eller bebyggelse av liten verdi) og tomt med høyverdig bebyggelse som dessuten vil kunne foranledige vanskelige avviklingsspørsmål, jf. pkt. 7.

\section{Partene: Hvem kan fremme krav overfor hvem?}

\subsection{Innledning}

Her i pkt. 5 forutsettes det at det i prinsippet foreligger et tilbakeføringskrav, men grunnlaget gir ikke svar på alt som vedrører gjennomføring av en tilbakeføring. Og da møter vi spørsmål om hvem kan fremme et slikt krav, og hvem som er riktig motpart. Når dette er avklart, blir det neste om hvorledes kravet kan fremmes. Spørsmålet om når det kan og må fremmes for å unngå rettstap, utskytes til pkt. 6 , og selve gjennomføringen av tilbakeføringen til pkt. 7.

\subsection{Avhender som kravshaver}

Vi starter med et enkelt eksempel: Som eier av bnr. 25 har A gitt tomt til en skole, og den har fått bnr. 50; nå er skolevirksomheten definitivt opphørt og bygningene er fjernet. Før vi kan svare på om A er rett kravshaver, må faktum presiseres:

(i) Tomten var den eneste faste eiendom A hadde på avgivelsestidspunktet, eller det var ingen rettslig eller faktisk tilknytning mellom den og Øvrig fast eiendom som A hadde på overføringstiden, eller

(ii) tomten var del av den eiendom som A eide på overføringstidspunktet, og A er fortsatt eier av moreiendommen (bnr. 25), eller

(iii) tomten var del av den eiendom som A eide på overføringstidspunktet, men eiendomsretten til moreiendommen (bnr. 25) er gått over til en annen.

I tilfelle (i) er det klarligvis A som kan fremsette krav, og det samme gjelder for (ii).

Tilfelle (iii) foranlediger spørsmål om retten er knyttet til A som person eller om den tilkommer den som til enhver tid er eier av bnr. 25. I første fall er det tale om en personlig rett, som kan være strengt personlig (retten faller bort når A dør), eller den kan være overførbar. Svarene her vil kunne bero på de 
konkrete forhold, ikke minst de arronderingsmessige, men utgangspunktet må nok være en presumsjon for at tomten skal gjenforenes med bnr. 25. Om man vil: Det dreier seg om en reell rettighet knyttet til moreiendommen.

En rettighetshaverposisjon knyttet til eierskap til moreiendommen kan imidlertid foranledige vanskeligheter der moreiendommen ikke lenger er den samme som på overføringstidspunktet. F.eks.: Bnr. 25 er i dag hovedbygningen med litt have rundt; resten er overført til naboeiendommen. Det enkleste er å si at retten tilligger bnr. 25, men gjenforeningssynspunktet trekker i retning av naboeiendommen. Er den opprinnelig eiendom i dag et stort antall bruksnummer, må man imidlertid som utgangspunkt holde på at bnr. 25 gir kravshaverposisjon - med mindre man finner at med den nåværende eiendomsstruktur er tilbakeføringsretten bortfalt.

\subsection{Motpart}

Adressat for tilbakeføringskravet er den som reelt er eier, ${ }^{24}$ og det kan være den B som eiendommen i sin tid ble overført til, eller B's suksessor med hensyn til eiendomsretten. ${ }^{25}$ Dersom B eller B's suksessor ikke er hjemmelshaver, kan det komme på tale å fremsette kravet også overfor den som sitter med hjemmelen.

Men her kan det oppstå tvil: For det første kan erververs identitet på etableringstidspunktet ha vært uklar. Grunnen er gitt til beste for «grend og bygd», til «speiderne», til «ungdomslaget» osv. - det er brukt diffuse betegnelser, og der betegnelsen er mer presis, dekker den ikke noen realitet (det er f.eks. aldri formelt stiftet noe ungdomslag). For det annet kan den identifiserte erverver ikke lenger eksistere - ungdomslaget/aksjeselskapet/Sportsklubben Grei er oppløst eller er gått i oppløsning. ${ }^{26}$ I slike tilfeller kan det nok hende at den berettigede tar eiendommen i besittelse så sant det ikke synes å være noen adressater eller konkurrerende pretendenter. Har hjemmelen vært hos den nå ikke-eksisterende enhet, kan det by problemer å bringe hjemmelen i orden. ${ }^{27}$

\footnotetext{
${ }^{24}$ Det kan tenkes at erverver ikke lenger trenger eiendommen. Et fortsatt eierskap betyr bare arbeid og utgifter uten at man får noe igjen for det - f.eks.: Det enkle idrettsanlegg som foreningens medlemmer i sin tid hadde stor glede av, er i dag uten interesse, man drar nå til den moderne kommunale idrettsarena. Her skal det nok helt særskilte omstendigheter til før erververen kan påtvinge avhenderen eiendommen.

${ }^{25} \mathrm{Her}$ kan det imidlertid ligge slik an at tilbakeføringsretten bare kan gjøres gjeldende overfor B, ikke senere eiere av eiendommen.

${ }^{26}$ Til illustrasjon, se Agder lagmannsretts dom 28. januar 1986: de Presno - Tromøy Speidertropp/Tromøy Speidertropps Mødreforening vedrørende grunneieren som gav speiderne rett til oppføring av en hytte: «Det foreligger ingen skriftlig avtale ... som kan fastslå hva avtalen går ut på. Det foreligger heller ingen korrespondanse eller annet skriftlig materiale som er egnet til å kaste lys over spørsmålet. ... Partene er enige om at det i 1953 ble avtalt at speiderne på parsellen Nesland fikk tillatelse til å sette opp en speiderhytte og å bruke den som hyttetomt.»

${ }^{27}$ Jf. Rt. 2007 s. 602: Fullmakt til å gi pantsettelsessamtykke kunne ikke godtas der hjemmelshaverselskapet var oppløst da tinglysing ble begjært. I lagmannsrettens avgjørelse (08-181674KSI-BORG/04), som ble stadfestet, sies det: «I enkelte saker aksepterer tinglysingsmyndigheten nødkompetanse fra det avviklede selskapet ved at
} 


\subsection{Kravsfremsettelse}

Kravsfremsettelse bør skje i skriftlig form, til den aktuelle eiers bosteds- eller forretningsadresse.

Blir kravet ikke akseptert, vil neste skritt kunne være søksmål etter de vanlige regler i tvisteloven (lov 90/2005). Her minnes bare om vernetingsreglene i tvistel. kap. 4 - se $\S 4-4$ om det alminnelige verneting og især § 4-5 første ledd om at sak kan anlegges «i den rettskrets hvor eiendommen ligger».

Kravsfremsettelse kan tenkes være initiert ved at eieren begynner å utnytte eiendommen på en måte som den berettigede mener utløser et tilbakeføringskrav. I en slik situasjon kan det tilspisse seg slik at det blir begjært midlertidig forføyning for å stanse den påbegynte nye utnyttelsesmåte, jf. tvistel. kap. $34 .^{28}$

Om fristavbrytelse der løsningsrettslov eller foreldelseslov (lov 18/1979) måtte komme til anvendelse, se nedenfor i pkt. 6.3 og 6.4 om de strengere krav som da stilles.

\section{Bortfall av tilbakeføringsretten \\ 6.1. Innledning}

Den som er berettiget til å fremme et tilbakeføringskrav, kan naturligvis frafalle det, idet kravet er aktuelt eller på et tidligere tidspunkt. Dette kan skje med klare ord, men også gjennom konkludent adferd eller passivitet. ${ }^{29}$ Er kravet knyttet til eierskap til avhendereiendommen, vil den aktuelle eiers avkall være bindende for senere erververe av eiendommen. Her i pkt. 6 forutsettes det at det ikke foreligger noen form for avkall, og videre at stiftelsesgrunnlaget ikke gir regler om når krav kan fremsettes med en siste frist for å kunne fremme et tilbakeføringskrav. Spørsmålet blir derfor om det for $\varnothing$ vrig finnes regler om at en tilbakeføringsrett kan gå tapt. Det synes nærliggende å anta at etter at

\footnotetext{
siste styre eller aksjonærene undertegner for det selskap som ikke lenger eksisterer. Etter det opplyste, er det praksis for å akseptere dette der et bostyre abandonerer eiendeler til fordel for en debitor og denne ikke lenger eksisterer som juridisk person.» Om en begrenset partsevne ved oppløsning/avvikling av selskaper, se Rt.1991 s. 656 (Norsk Business Management), Rt. 1991 s. 1386 (First Norwegian Trading) og HR-1991-249-K

(Nordaustpol). I særlige tilfeller kan det synes ikke å være noen som eiendommen kan tilbakeføres til, og at det heller ikke er noen aktuell eier. Slike situasjoner ligger utenfor rammen for nærværende artikkel.

${ }^{28}$ Jf. Rt. 1938 s. 468: «Selv om en ekspropriat måtte ha rett til å løse tilbake en ekspropriert eiendom når det er bragt på det rene at den ikke vil bli benyttet til det øiemed som dannet grunnlaget for ekspropriasjonen, kan ikke dette avskjære eksproprianten fra å benytte eiendommen på annen måte så lenge tilbakeløsning ikke er skjedd. Noget annet antas ikke å kunne gjelde om forholdet - som i det foreliggende tilfelle - er det at ekspropriaten alt har fremsatt krav på tilbakelevering før den nye anvendelse er gjennomført. Men eksproprianten må selvfølgelig i et sådant tilfelle handle på egen risiko, således at tilbakesøkningen i tilfelle kan utøves uavhengig av de av eksproprianten trufne forføininger.»

${ }^{29}$ F.eks.: Skoletomten blir gradvis tatt i bruk også for andre formål samtidig som skoleaktiviteten avtar - alt uten at den berettigede gjør innvendinger.
} 
tilbakeføringsgrunnlag foreligger, eller etter at det bør være kjent for den berettigede at så er tilfellet, kan det ikke ventes i ubegrenset tid med å fremme et krav.

\subsection{Kravsfremsettelse innen rimelig tid?}

Den alminnelige lojalitetsplikt tilsier at den berettigede varsler om sin rett når forholdene har endret seg slik at han mener at retten er blitt aktualisert - helt klart er dette der han ser at den annen part er i gang med investeringer $i$ arealet eller på annet vis innretter seg som om hans rett til arealet vil bestå.

Hvor sterkt kan tidens tann gnage?

Sterkest står den berettigede hvis vi legger til grunn at hans rett er «tinglig» (jf. nedenfor). Her kan imidlertid tilbakeføringsretten gå tapt etter reglene om hevd, f.eks. der B's suksessor i god tro i hevdstid bruker eiendommen i strid med formålsangivelsen. Men også før så lang tid er gått, kan tilbakeføringsretten være tapt etter ulovfestede passivitetsregler. ${ }^{30}$

\subsection{Er løsningsrettsloven av betydning?}

Dersom en avtalt tilbakeføringsrett må ansees som en lфsningsrett, slik løsningsrettsloven (lov 64/1994) bestemmer begrepet, har denne lov visse regler om frist for kravsfremsettelse ( $§ 12)$ og om en absolutt grense for å kunne kreve tilbakeføring uten hensyn til de subjektive forhold ( $\$ 6$, jf. $\S 23)$.

I LG-2017-29601 måtte Gulating lagmannsrett ta standpunkt til anvendelsen av § 6 som har den hovedregel at en løsningsrett opphører 25 år etter stiftelsen, likevel slik at etter $\S 23$ opphører rettigheter etablert før loven trådte i kraft, tidligst 1. juli 2015. Faktum i saken var i hovedtrekk:

I sitt testament hadde A bestemt at hans verdier, bl.a. eiendommen Fredheim, skulle tilfalle et legat - med angivelse av at Fredheim kunne stilles til disposisjon som bolig for biskopen i Stavanger. Etter endel forhandlinger mellom legatet og myndighetene endte det med at Fredheim i 1966 ble tilskjøtet Opplysningsvesenets Fond (OVF). I skjøtet het det:

«Hvis endrede forhold gjør det umulig å nytte eiendommen som bispebolig, eller andre grunner gjør det mer hensiktsmessig at Biskopens leieforhold blir ordnet på annen måte, kan Legatet kreve eiendommen tilbakeført til seg vederlagsfritt og fri for pengeheftelser.»

Da slikt krav ble fremsatt i 2016, hevdet OVF at dette var et krav som falt inn under løsningsrettsloven, og at fristen for å påberope seg retten utløp i 2015, jf. løsningsrettsl. $§ 23$.

\footnotetext{
${ }^{30}$ Se f.eks. Falkanger \& Falkanger, op. cit. s. 345-347.
} 
Lagmannsretten fant at skjøtningen i 1966 innebar en eiendomsoverdragelse, og videre at det var «klart at den rettighet som beskrives er en løsningsrett» - og dermed tapte legatet.

Saken ble innbragt for Høyesterett, som kom til samme resultat (HR2018-1906): Man fant det «ikke tvilsomt at eiendomsretten til Fredheim ble overført fra legatet til OVF i 1966» (avsnitt 46). Etter en detaljert gjennomgang av lovforarbeidene konkluderes det med at skjøtebestemmelsen er «en løsningsrett som faller inn under løsningsrettsloven» (avsnitt 75). ${ }^{31}$

I skjøtet var det imidlertid bestemt at eiendommen «kan ikke nyttes til andre formål uten Legatstyrets samtykke». OVF mente at når løsningsretten ikke kunne gjøres gjeldende, var samtykkeklausulen også bortfalt. Dette var Høyesterett ikke enig i: Legatet hadde sikret seg «en rett til tilbakeføring som kom i tillegg til samtykkeklausulen» (avsnitt 83). ${ }^{32}$

Vedrørende 25-årsbegrensningen minnes det om at den ikke gjelder for løsningsrett (tilbakeføringsrett) «som ligg til ein annan fast eigedom, når retten gjeld grunn som er utskild frå eigedomen eller som er høveleg til å slåast saman med den» ( $\$ 6$ annet ledd bokstav a). I det klassiske tilfelle: fra gårdsbruket er det fradelt tomt til skole eller grendehus, løper det ingen foreldelsesfrist etter løsningsrettsloven. ${ }^{33}$ Videre minnes om at fristen er 50 år der retten ligger til «føretak og gjeld grunn til utviding eller tilfang til drift av føretaket» (tredje ledd). ${ }^{34} \mathrm{Og}$ endelig, i fjerde ledd sies det at reglene i første og tredje ledd er ufravikelige.

Fristen, som regnes fra stiftelsestiden, brytes ved at det fremsettes et skriftlig krav overfor «eigaren av eigedomen» (§13).

Løsningsrettsloven gjelder rettigheter med privatrettslig grunnlag, men også for så vidt er det en begrensning i § 1 tredje ledd: Loven får ikke anvendelse på «løysingsrettar som har heimel i lov, med mindre noko anna er fastsett». Det tilbakeføringskrav vi har for øye, har ikke sin hjemmel i lov, men beror på mer alminnelige kontraktsforutsetninger. Slike krav må falle innenfor løsningsrettslovens prinsipielle anvendelsesområde: Det er ingen rimelig grunn til å gi forutsetninger av denne art større motstandskraft enn den uttrykkelige avtalebestemmelse.

\footnotetext{
${ }^{31}$ Det var en rekke andre spørsmål som ble drøftet, bl.a. om regelen var en tilbakevirkning i strid med Grunnlov og EMK. Disse er det ikke nødvendig å omtale her.

${ }^{32}$ Fra avsnitt 84 gjengis: «OVF har blant annet anført at samtykkeklausulen ikke har noen betydning fordi det ville innebære misbruk om den ble benyttet, og at den uansett ville bli endret eller fjernet etter reglene om omskiping og avskiping i servituttloven. Til det vil jeg for det første si at jeg ikke har grunnlag for å forutsette at en fremtidig nektelse av samtykke vil innebære maktmisbruk. Dernest bemerker jeg at retten selvsagt ikke nå slutter å gjelde selv om en mulig senere utvikling kan føre til endringer.» Jf. også Rt. 1938 s. 468, omtalt i note 28.

${ }^{33}$ Her kan vi imidlertid møte problemer der avgivereiendommen er blitt delt, kanskje mange ganger.

${ }^{34}$ F.eks.: A overlater et areal til B for et bestemt formål, men med bestemmelse om at arealet må tilbakeføres dersom A trenger det for driften av sitt foretak.
} 
Kjernepunktet i argumentasjonen i Fredheim-saken er at en eiendomsovergang hadde funnet sted: Muligheten (opsjonen) til å kreve eiendommen tilbakeført var tapt. Hvis det isteden hadde vært en leiekontrakt, si for 20 år, ville leietagerens tilknytning uten videre opphørt idet de 20 år var omme. Slik må det også være der varigheten er bestemt på annet vis, f.eks. så lenge eiendommen brukes som bispebolig. En annen variant er at erververen må gi fra seg rådigheten («eiendomsretten») når noe ikke er skjedd innen en viss frist (f.eks.: eiendommen/rådigheten går tilbake dersom det på en angitt dato ikke foreligger reguleringsplan for fritidsbebyggelse). Et opsjonselement får vi derimot ved en leieavtale som løper inntil den blir oppsagt av utleieren; den opsjon som utleier her har, faller imidlertid utenfor løsningsrettsloven. ${ }^{35}$

Det avgjørende for løsningsrettslovens anvendelse synes derfor å være at det foreligger en opsjon for avhender (eller den han måtte ha overdradd opsjonsretten til) til å sette strek for erververs eiendomsrådighet. ${ }^{36}$

Et konkret eksempel: A har et areal i strandsonen, og det kan ikke utnyttes. B har hytte der, men hans tomt er i minste laget. A overfører sitt areal til B, men med bestemmelse om at arealet skal eller kan bli tilbakeført dersom ny regulering gjør tomten bebyggelig. Med kan er det et opsjonsmoment som gjør løsningsrettsloven anvendelig. Med skal er det intet opsjonsmoment, men med en mulighet for at man pr. fortolkning finner at skal her må forstås som kan. Hvis A skal unngå løsningsrettsloven, synes det tryggest å velge en oppsigelig leieavtale.

Der løsningsrettsloven er anvendelig, er det ikke bare fristregelen i § 6 som kan være av betydning: Loven har også regler om når krav senest må fremsettes, men de er begrenset til forkjøpsrettstilfellene, jf. § 12. Utenom disse må man også her falle tilbake på «rimelig tid». ${ }^{37}$

\subsection{Kan et tilbakeføringskrav foreldes etter reglene i foreldelsesloven?}

Løsningsrettsloven har, som vi har sett i foregående punkt, regler om foreldelse/bortfall etter lengre tid, regnet fra stiftelsestidspunktet. Hvis foreldelsesloven (lov 18/1979) er anvendelig, kan det bli tale om betydelig strammere regler: Er et aktuelt tilbakeføringskrav en «fordring» som nevnt i foreldelsesl. § 1, og dermed som hovedregel underlagt en foreldelsesfrist på tre år $(\S 3)$ ?

\footnotetext{
35 Jf. Ot.prp. nr. 49 (1993-94) s. 23: «Lova vil derimot ikkje gjelde for løysingsrett til andre grunnleigerettar enn tomtefeste, og heller ikkje løysingsrett til andre totale eller avgrensa bruksrettar til fast eigedom ... ...» ${ }^{36}$ Dette kan være et eierforhold som kan være underlagt begrensninger. I ervervsdokumentet ligger f.eks. restriksjoner som må oppfattes som negative servitutter, eller restriksjoner av annen art, f.eks. salgs- eller pantsettelsesinnskrenkninger.

${ }^{37}$ Jf. Falkanger, Løsningsrettsloven (2015) s. 119-120.
} 
Her er det naturlig å ta utgangspunkt i avgjørelsen i Rt. 2012 s. 506 (Åslandseter), der det bl.a. sies:

«At en eiers vindikasjonskrav som utgangspunkt ikke foreldes, er utvilsomt. Det tvisten gjelder er om dette utgangspunkt kan opprettholdes når det reises krav om tilbakeføring av en eiendom som er overdradd i henhold til en avtale som forutsetningsvis er ugyldig fordi avhenderen mangler rettslig handleevne» (avsnitt 21).

Høyesterett konkluderte med at tilbakeføringskravet ikke var foreldet. At et restitusjonskrav overfor den som har ervervet ved en avtale som ikke er bindende, ikke foreldes

«er et utslag av en innarbeidet rettstradisjon, synes forutsatt av lovgiver og har hatt alminnelig tilslutning i teorien over lang tid. Jeg kan ikke se at det er noen grunn til å fravike denne forståelse av foreldelsesloven» (avsnitt 34). ${ }^{38}$

\section{Men er det et vindikasjonskrav når skoletomten begjæres tilbakeført idet} skolevirksomheten opphører? Eller er kravet snarere i klasse med kjøpekontrakten som utvilsomt er gjenstand for foreldelse. ${ }^{39}$ Slik foreldelse kan inntre også om kjøpesummen er betalt. ${ }^{40}$ Det er her i kjøpsforhold tale om en rett som kan kreve en rekke handlinger før den kan anses gjennomført, og anvendelsen av foreldelsesloven avskjæres først idet kjøperen blir «eier». Retten til å kreve tilbakeføring har så mange likhetstrekk med den tradisjonelle kjøpekontrakt at meget kan tale for at retten bør være underlagt foreldelsesreglene.

I forarbeidene til løsningsrettsloven er det omfattende drøftelser av tap av løsningsrett ved passivitet og foreldelse, herunder etter foreldelsesloven. ${ }^{41}$ Det er især pekt på at forarbeidene til foreldelsesloven klart gir uttrykk for at foreldelse kan skje:

«Det er uten betydning hva slags ytelse fordringen går ut på, f eks penger (som er særskilt nevnt i lovteksten), varer, individuelt bestemte ting, fast eiendom eller arbeidsytelser. Det er derfor ikke noe til hinder for at en avtalt - men ikke fullbyrdet rett til å få rådighet over løsøre eller fast eiendom kan foreldes, selv om erververen har oppnådd omsetningsvern for sin rett ved tinglysing eller på annen måte (jf Rt-1923202). Dette gjelder også avtalte løsings- og forkjøpsretter. - Det er også uten betydning hvilket juridisk grunnlag fordringen har, om den bygger på avtale, rettsbrudd, eller om den har familierettslig eller offentligrettslig grunnlag.

\footnotetext{
${ }^{38}$ I LB-2015-78068 gjaldt det en dødsgave som ble underkjent fordi formkravene ikke var iakttatt, men lagmannsretten fant at arvingenes (nevøenes) krav var gjenstand for foreldelse:

«Saken her ligger annerledes an [enn i Rt. 2012 s. 506]. En slik rett til vindikasjon, som ikke foreldes, er en rett i kraft av eiendomsrett. Nevøene har i et tilfelle som dette ... ingen eiendomsrett til eiendommen eller noe krav på å være (del-)eiere, og de har aldri vært eiere av den.»

${ }^{39}$ Her møter vi sondringen tinglig/obligatorisk, som har vært gjenstand for endeløse diskusjoner - som det ikke skal ytes noe bidrag til her. Det er imidlertid et faktum at foreldelsesloven må leses på bakgrunn av lovgiverens oppfatning av en slik sondring, som innebærer at «tinglige rettigheter» faller utenom foreldelsesloven.

${ }^{40}$ Jf. Kjørven m.fl., Foreldelse av fordringer (2011) s. 79 flg.

${ }^{41}$ Jf. især NOU 1984: 32 s. 32-34, s. 56 og s. 71, og Ot.prp. nr. 49 (1993-94) s. 28-32 og s. 50-52.
} 
Derimot er de tinglige rådighetsretter ikke å betrakte som fordringer og er heller ikke gjenstand for forelding. Disse kan bare falle bort ved hevd eller annet ekstinktivt erverv. Såleis foreldes ikke en eiers vindikasjonsrett, en leietakers aktuelle bruksrett eller en servitutthavers aktuelle servituttrett» (Ot.prp. nr. 49 (1993-94) s. 30-31).

Etter foreldelsesl. $\S 3$ nr. 1 begynner foreldelsen å løpe fra den dag «da fordringshaveren tidligst har rett til å kreve oppfyllelse». Nøyaktig når dette er, kan være høyst problematisk for de krav vi har for øye. Når opphørte f.eks. foreningsaktiviteten slik at krav kunne fremmes? Svaret kan bero både på faktum og jus: Hva er hendelsesforløpet, og når var utviklingen kommet så langt at krav kunne fremsettes? Det problematiske ved denne objektive regel dempes imidlertid noe ved $\$ 10 \mathrm{nr} .1 \mathrm{om} \mathrm{krav}$ som ikke er fremsatt fordi den berettigede har «manglet nødvendig kunnskap om fordringen eller skyldneren». I så fall inntrer foreldelse «tidligst 1 år etter den dag da fordringshaveren fikk eller burde skaffet seg slik kunnskap».

Etter løsningsrettsl. $§ 13$ kreves skriftlig kravsfremsettelse. Foreldelsesl. $\S 15$ krever som hovedregel at det tas «rettslig skritt mot skyldneren». Fristen brytes altså ved at det tas ut stevning. Om verneting, se ovenfor i pkt. 5.4.

\subsection{Kan tilbakeføringsretten gå tapt ved ekstinksjon?}

Hviler tilbakeføringsretten som en heftelse på eiendommen, vil den kunne gå tapt etter reglene om ekstinksjon i kraft av tinglysingsreglene. F.eks. slik: A overfører tomten til $\mathrm{B}$, som får hjemmel til tomten uten at det av det tinglyste fremgår at A etter omstendighetene kan ha et tilbakeføringskrav. Når B selger til $\mathrm{C}$ som ikke vet eller bør vite noe om bakgrunnen idet han får tinglyst sitt erverv, kan et tilbakeføringsretten ikke gjøres gjeldende overfor ham, jf. tinglysingsl. (lov 7. juni 1935 nr. 2) $§ 27$.

\section{Gjennomføring og oppgjør}

Det forutsettes her at stiftelsesgrunnlaget ikke sier noe om gjennomføring og oppgjør etter at tilbakeføringskrav er fremsatt.

Når kravet er fremsatt av A overfor B, kan det uten videre bli akseptert, hvoretter partene forhandler seg frem til en avvikling av B's forhold og en overføring av eierrådigheten til A. Skjer ikke det, vil A kanskje måtte gå til søksmål mot B og få dom for sin rett. I verste fall kan det bli tale om tvangsgjennomføring av en fullbyrdelsesdom, jf. tvfbl. (lov 86/1992) kap. 13.

Utgangspunktet må være at $\mathrm{B}$ avvikler sin virksomhet på eiendommen innen rimelig tid, og at han bidrar til å få hjemmelen overført til A. Utgiftene 
ved hjemmelsoverføring må imidlertid A bære, sml. tomtefestel. (lov 106/1996) $\S 38$ første og annet ledd.

Et viktig punkt er i hvilken stand A kan forvente at eiendommen er ved tilbaketagningen - fysisk og heftelsesmessig.

Her må det sondres ettersom B's utnyttelse har vært i samsvar med forutsetningene - at eiendommen er blitt endret (vegetasjon er fjernet, veiinngrep er foretatt osv.), gir ikke A noen innsigelser eller krav så lenge det dreier seg om forandringer/inngrep som er rimelige hensett til formålet med ervervet. Har bruk utenfor denne ramme gitt en verdireduksjon, kan det føre til et krav fra A's side. - og forsåvidt kan oppgjørsreglene ved ugyldighet og hevning (jf. foran i pkt. 3.2 og 3.3) gi veiledning. Også heftelser må vurderes på tilsvarende vis; en pantsettelse til sikring av de investeringer som var fornuftige hensett til formålet med ervervet, kan A neppe gjøre innsigelser overfor.

I Rt. 1939 s. 926 om tilbakeføring av tomt gitt med formål tuberkulosehjem ble, som omtalt i pkt. 4.2.1, tilbakeføring akseptert. Lagmannsretten kommer her med en ganske kategorisk og ikke nærmere begrunnet uttalelse:

«At eiendommen pliktes levert tilbake i heftelsesfri stand, slik den ble skjenket, finner vi ikke tvilsomt. Hvis panthaverne ikke efter dommen vil frafalle pant i b.nr. 5 og 6 , må det være Storm og Monsens [gavemottagernes] sak å utvirke at de gjør det» (s. 929-930).

Bebyggelsen foranlediger noen nærmere bemerkninger - fortsatt under forutsetning av at ikke noe kan utledes av stiftelsesgrunnlaget. Bebyggelsen kan være et verdiminus - hytta er forfallen, den må rives og materialrestene bortkjøres. Men det kan dreie seg om bebyggelse som har sin verdi, også for A.

Tomtefestel. kap. VII har regler om avvikling av tomtefeste. Etter $\$ 39$ har festeren rett og plikt til «å ta bort hus og andre faste tilskipingar». Dette synes å være en velbegrunnet regel som må kunne anvendes også i forholdet mellom A og B. Og de prinsipper som er nedlagt i § 40 med sikte på å unngå verdispille «i utrengsmål», bør også ha sin klare overføringsverdi. At vi her vil stå overfor vederlagsspørsmål, må være på det rene, men den nærmere utforming av dem $\mathrm{i}$ $\S 41$ er så vidt spesiell at det er grunn til forsiktighet med en tilsvarende anvendelse. Også reglene der ekspropriasjonsvedtak omgjøres og eiendommen tilbakeføres, er av interesse, jf. oreigningsl. § 10 annet ledd første og annet punktum: Ekspropriasjonserstatningen tilbakebetales, med fradrag for eventuell ulempeerstatning for tiden frem til ekspropriaten får tilbake rådigheten. Verdiendringer som følge av det som er «gjort med eigedomen», tas i betraktning - med fradrag der endringen er negativ, med tillegg der ekspropriaten har tilført verdier. 